https://doi.org/10.46813/2021-135-037

\title{
ANALYSIS OF STRUCTURAL TRANSFORMATIONS IN NATURAL QUARTZITES UNDER THE INFLUENCE OF GAMMA IRRADIATION
}

\author{
E.P. Bereznyak, N.P. Dikiy, I.V. Kolodiy, E.P. Medvedeva, Yu.S. Khodyreva \\ National Science Centre "Kharkov Institute of Physics and Technology", \\ Kharkiv, Ukraine \\ E-mail: bereznyak@kipt.kharkov.ua
}

\begin{abstract}
Using the methods of IR spectroscopy, crystal-optical and XRD analysis the evolution of the structure of Ovruch deposit natural quartzites under the influence of $\gamma$-irradiation in the range of absorbed doses $\left(\mathrm{D}_{\mathrm{abs}}=10^{6} \ldots 3.5 \cdot 10^{7} \mathrm{~Gy}\right)$ has been researched. The elemental composition of natural quartzites was determined by the gamma activation method on a linear electron accelerator. It was found that as a result of irradiation the crystal structure of quartz, which forms the basis of quartzite, is improved due to radiation annealing of the defects in the initial structure. At the same time crystallization of amorphous silica, which fringes large grains of quartz, occurs with its transformation into fine-crystalline quartz. These processes do not lead to cracking in the quartzite rock. Obtained data indicates a high radiation resistance of the Ovruch deposit quartzites and confirms the prospects of using this geological formation as a natural barrier for the construction of radioactive waste long-term storage.
\end{abstract}

PACS: 539.2:549.2:535.33

\section{INTRODUCTION}

One of the main tasks of the nuclear power industry is the secure isolation of radioactive waste (RAW). The most reliable and long-term isolation of RAW can be ensured by their burial in a stable deep geological formations, which include the rocks of the Ukrainian crystalline shield and part of which is located in the exclusion zone of the Chernobyl nuclear power plant [1-3]. One of the main factors ensuring the stability of the geological environment during deep RAW disposal is its radiation resistance. In our previous works $[4,5]$ we studied the influence of irradiation with accelerated electrons on the structure and phase composition of the Ovruch deposit quartzites in the northeastern part of the Zhitomir region, which are potentially suitable for the construction of RAW storage there. It was established that the investigated quartzites are highly resistant under the conditions of irradiation imitation with high-energy electrons, which were used for the accelerated set of doses corresponding to the long times of real irradiation from RAW. However radiation fields affecting the geological environment from the side of container with RAW mainly consist of $\gamma$-radiation, since charged particles ( $\alpha$ - and $\beta$-radiation) are absorbed by the protective container [6]. In addition, it was necessary to investigate the impact of the dose rate and, accordingly, the time required for its collection by the exploring material on the structural transformations degree. The aim of this work was the analysis of the structural transformations in natural quartzites under the influence of the long term irradiation with $\gamma$-quanta.

\section{EXPERIMENTAL TECHNIQUE}

Irradiation was carried out on the linear electron accelerator KUT-1 using bremsstrahlung gamma radiation generated by the interaction of an electron beam with a thick aluminum absorber (the boundary electron energy was $12 \mathrm{MeV}$, the beam current was $450 \mu \mathrm{A}$, the pulse frequency was $200 \mathrm{~Hz}$, the pulse duration was $3.8 \mu \mathrm{s}$ ).
The dose of $\gamma$-irradiation was determined using a thermoluminescent detector made of lithium fluoride, activated with calcium, magnesium and titanium and was $\mathrm{D}_{\mathrm{abs}}=1 \cdot 10^{6} \ldots .3 .5 \cdot 10^{7} \mathrm{~Gy}$. Specified dose range was chosen because it is known that the maximum dose of external radiation from the RAW, which can be collected by the geological environment for 1000 years, is equal $\sim 3 \cdot 10^{7} \mathrm{~Gy}$ [7]. Irradiation to a dose of $10^{6} \mathrm{~Gy}$ lasted for a month, to a dose of $10^{7} \mathrm{~Gy}-$ for 7 years, to a dose of $3.5 \cdot 10^{7} \mathrm{~Gy}-$ for 12 years. The structure and phase composition of quartzites were investigated by infrared (IR) spectroscopy, crystal-optical and XRD analysis. Infrared absorption spectra were recorded on an IRS-29 (LOMO) spectrophotometer in the frequency range of $400 \ldots 4000 \mathrm{~cm}^{-1}$ with a measurement error of $\pm(2 \ldots 7) \mathrm{cm}^{-1}$. Crystal-optical studies were carried out on polarizing microscopes MIN-8, POLAM-211L using immersion liquids. XRD analysis was conducted on DRON-4-07 diffractometer in copper $\mathrm{Cu}-\mathrm{K} \alpha$ radiation using nickel selective-absorbing filter.

The samples of quartzite and standards in aluminum container were irradiated under the bremsstrahlung from the electron accelerators with the energy of $23 \mathrm{MeV}$ and current $500 \mu \mathrm{A}$ [8]. Activation of samples carried out on air, the temperature of samples in the course of the activation did not exceed $40^{\circ} \mathrm{C}$.

The determination of elements content in samples was performed by gamma spectrometer method in $\mathrm{Ge}(\mathrm{Li})$-detector with the volume of $50 \mathrm{~cm}^{3}$ and resolution of 3.2 at $1332 \mathrm{keV}$ line. To reduce the influence of the background, the detector is equipped with a threelayer $\mathrm{Pb}-\mathrm{Cu}-\mathrm{Al}$ protection. The errors of measurements were from 7 to $25 \%$. The limit of detection elements for photo activation analyses was $10^{-4} \mathrm{wt} . \%$.

\section{RESULTS AND DISCUSSION}

Quartzite is a metamorphic rock, consisting mainly of $\alpha$-quartz, volume fraction of which in the rock is $90 \ldots 98 \%$ [9]. The study of the structure of the initial 
quartzite using crystal-optical analysis showed that it consists of large oval grains of $\alpha$-quartz, tightly adjacent to each other. Each grain of quartz is surrounded by a thin border of amorphous silica, which was formed during the formation of quartzites under conditions of intense exposure of temperature and pressure (Fig. 1). The width of the amorphous silica interlayer is $8 \ldots 13 \mu \mathrm{m}$.

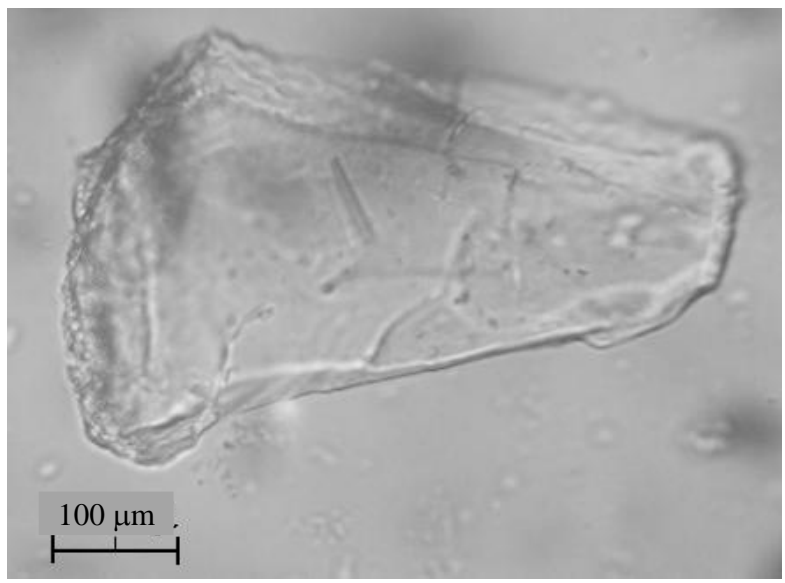

Fig. 1. Micrograph of a grain of the initial quartzite in an immersion preparation. In transmitted light, without analyzer. Transparent quartz grain surrounded by an amorphous silica border

After irradiation with $\gamma$-quanta to a dose of $10^{6} \mathrm{~Gy}$, crystal optical analysis revealed the formation of a large number of opaque point inclusions size of $1 . .2 \mu \mathrm{m}$ in quartz grains due to radiation-stimulated diffusion of the impurities and their accumulation in the lattice voids (Fig. 2). The appearance of the amorphous silica border surrounding the quartz grains does not change.

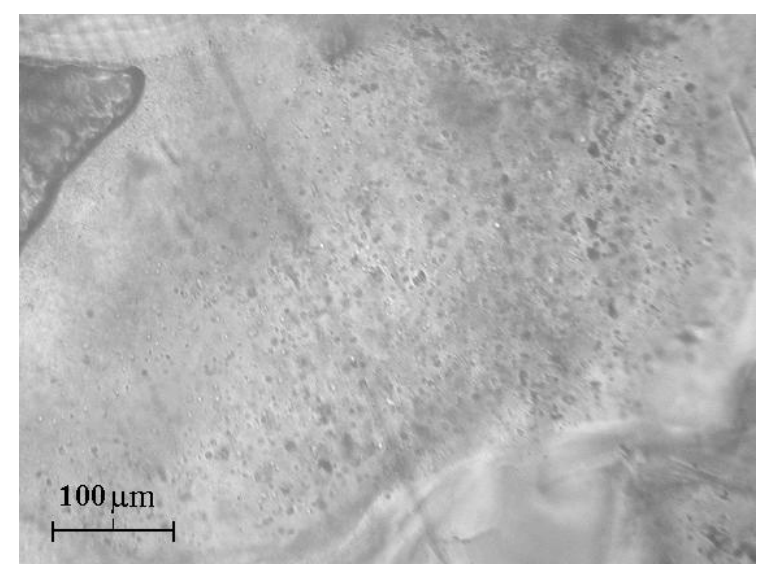

Fig. 2. Micrograph of quartzite in an immersion preparation after irradiation to a dose of $10^{6} \mathrm{~Gy}$.

In transmitted light, without analyzer.

Opaque point inclusions in quartz grains

Irradiation to a dose of $10^{7}$ Gy leads to the formation of clusters in the quartz grains consisting of opaque inclusions or oriented chains of gas-liquid inclusions located in structural channels. Silica fringes around quartz grains look like a completely transparent crystalline substance (Fig. 3).

As a result of irradiation to a dose of $3.5 \cdot 10^{7} \mathrm{~Gy}$, quartz grains acquire a smoky color and sometimes lose their transparency due to the presence of a large number of inclusions and impurities (Fig. 4). At the same time, there is no visible cracking or amorphization of the quartz structure, and the silica rims up to $10 \mu \mathrm{m}$ wide consist of polycrystalline quartz.

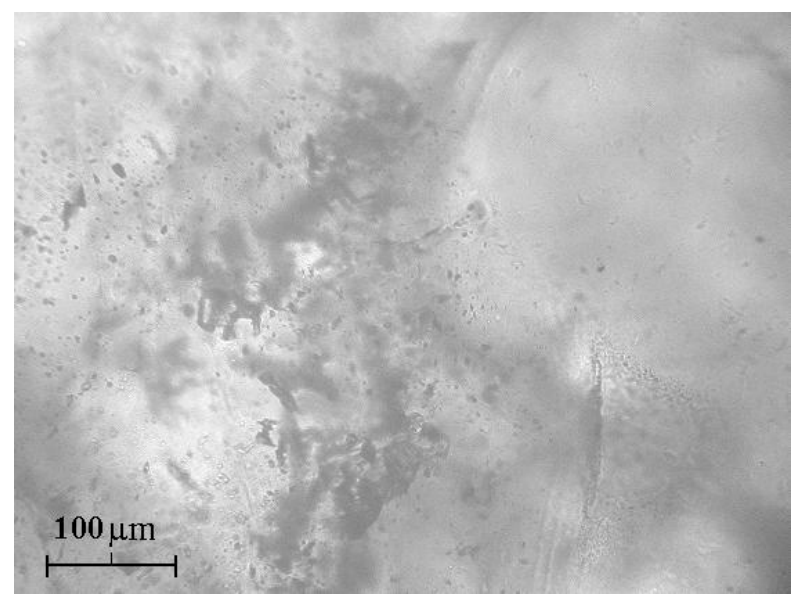

Fig. 3. Micrograph of quartzite in an immersion preparation after irradiation to a dose of $10^{7} \mathrm{~Gy}$. In transmitted light, without analyzer. Clusters and chains of opaque point inclusions in a quartz grain

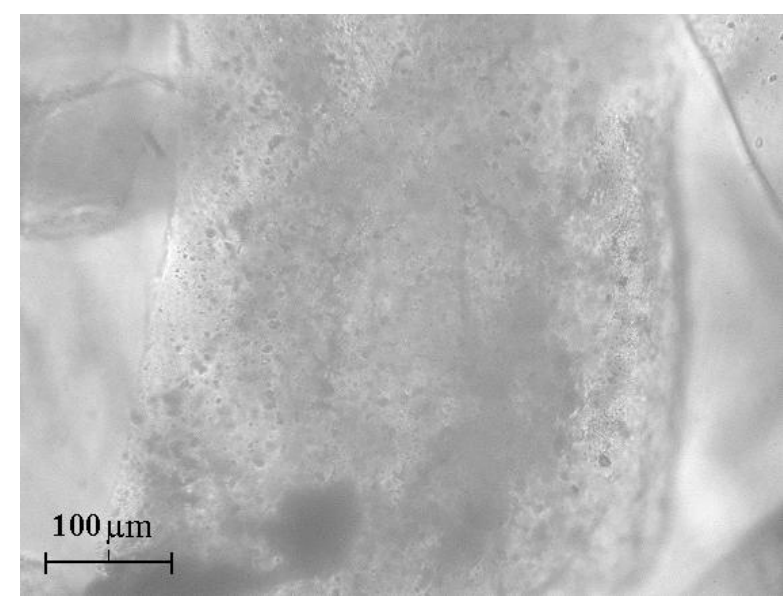

Fig. 4. Micrograph of quartzite in an immersion preparation after irradiation to a dose of $3.5 \cdot 10^{7} \mathrm{~Gy}$. In transmitted light, without analyzer

On the diffraction pattern of the initial quartzite (Fig. 5, curve 1), the position of the maxima and their integrated intensity fully correspond to polycrystalline quartz. The lattice parameters are: $a=4.9140 \AA, c=$ $5.4075 \AA$. Literature data (ICDD PDF-2 database No. 85-0798): $a=4.914 \AA ; \quad c=5.405 \AA$, hexagonal structure, space group No. 154. A larger value of the parameter $c$ indicates the presence of defects in the original structure.

After $\gamma$-irradiation to a dose of $\mathrm{D}=1 \cdot 10^{6} \mathrm{~Gy}$ (see Fig. 5, curve 2), a decrease in the lattice parameters is observed in comparison with the initial sample. The lattice parameters are: $a=4.9125 \AA, c=5.4048 \AA$.

With an increase in the irradiation dose to the value $\mathrm{D}=1 \cdot 10^{7} \mathrm{~Gy}$ (see Fig. 5, curve 3 ), there is a slight increase in the parameter $\boldsymbol{a}$ in comparison with the previous sample, while the parameter $c$ does not change. The measured lattice parameters are: $a=4.9131 \AA(\Delta \mathrm{a}=$ $6 \cdot 10^{-4} \AA$, about $\left.0.01 \%\right), c=5.4047 \AA$. It is also worth noting a slight increase in the half-width of the lines $\left(0.02 \ldots 0.05^{\circ}\right)$ compared to irradiation up to a dose of 
$\mathrm{D}=1 \cdot 10^{6} \mathrm{~Gy}$, although these changes are at the limit of the measurement error. Changes in diffraction peaks intensity are also insignificant. After $\gamma$-irradiation of the sample to a dose of $\mathrm{D}=3.5 \cdot 10^{7} \mathrm{~Gy}$ (see Fig. 5, curve 4), the quartz lattice parameters are: $a=4.9135 \AA$, $c=5.4062 \AA$. It is seen that the parameter $\boldsymbol{a}$ within the measurement error corresponds to the previous sample. The parameter $c$ has increased in comparison with the previous sample to the value $c=5.4062 \AA \quad(\Delta \mathrm{a}=$ $=1.5 \cdot 10^{-3} \AA$, approximately $0.03 \%$ ).

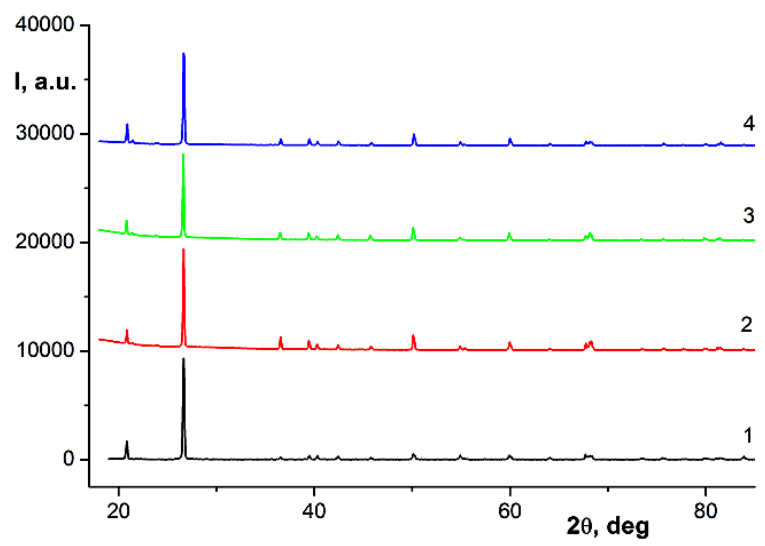

Fig. 5. Diffraction patterns of quartzite:

1 - initial quartzite; 2 - irradiation with $\gamma$-quanta up to a dose of $10^{6} \mathrm{~Gy} ; 3$-irradiation with $\gamma$-quanta up to a dose of $10^{7} \mathrm{~Gy} ; 4$-irradiation with $\gamma$-quanta up to a dose of $3.5 \cdot 10^{7} \mathrm{~Gy}$

Thus, it can be seen that at an irradiation dose $\mathrm{D}=1 \cdot 10^{6} \mathrm{~Gy}$, the lattice parameters of quartz are lower than in the initial sample, which can be explained by the radiation annealing. With a further increase in the irradiation dose a slight increase in the lattice parameters is observed. Although even at the maximum irradiation dose $\mathrm{D}=3.5 \cdot 10^{7} \mathrm{~Gy}$, the lattice parameters are lower than in the initial state; the accumulated doses of $\gamma$ irradiation turned out to be insufficient for the significant formation of radiation defects in the quartzite structure (Table 1).

Table1

Lattice parameters of investigated quartzite samples

\begin{tabular}{|c|c|c|c|}
\hline \multirow{2}{*}{$\begin{array}{c}\text { Dose } \mathrm{D}, \\
\mathrm{Gy} \cdot 10^{7}\end{array}$} & \multicolumn{2}{|c|}{ Lattice parameters } & \multirow{2}{*}{$\begin{array}{c}\text { Volume } \\
\text { cell V, } \AA^{3}\end{array}$} \\
\cline { 2 - 3 } 0 & $a, \AA$ & $c, \AA$ & 113.08 \\
\hline 0.1 & 4.9140 & 5.4075 & 112.96 \\
\hline 1.0 & 4.9131 & 5.4047 & 112.98 \\
\hline 3.5 & 4.9135 & 5.4062 & 113.03 \\
\hline
\end{tabular}

In the IR spectrum of the initial quartzite there are main absorption bands of $\alpha$-quartz: 465, 700, 810, $1100 \mathrm{~cm}^{-1}$, typical for $\mathrm{Si}-\mathrm{O}$ vibrations. However, the absorption bands are somewhat blurred, and in the range of $830 \ldots 750 \mathrm{~cm}^{-1}$ there is no doublet due to the $v_{\mathrm{s}}$ $\mathrm{Si}-\mathrm{O}-\mathrm{Si}$ vibrations, which indicates the presence of an amorphous component in the form of silica cement, as well as the presence of defects and impurities in the initial structure of the quartz, constituting the quartzite. The presence in the spectrum of absorption bands of medium intensity in the frequency range of 1600 and $3400 \mathrm{~cm}^{-1}$ indicates the presence of $\mathrm{OH}^{-}$groups in the initial sample, and a small peak in the region of $1400 \mathrm{~cm}^{-1}$ is associated with an impurity of the carbonate phase (Fig. 6, curve 1).

In the spectrum of quartzite after irradiation to a dose of $1 \cdot 10^{6} \mathrm{~Gy}$, an increase in the intensity of all the main absorption bands corresponding to $\alpha$-quartz is observed; doublets of 780,810, and $1080,1120 \mathrm{~cm}^{-1}$ (see Fig. 6, curve 3) typical for low-temperature quartz are clearly appeared. This indicated that upon irradiation to the first dose radiation annealing of the initial defects in $\alpha$-quartz, which constitutes the quartzite, occurs.

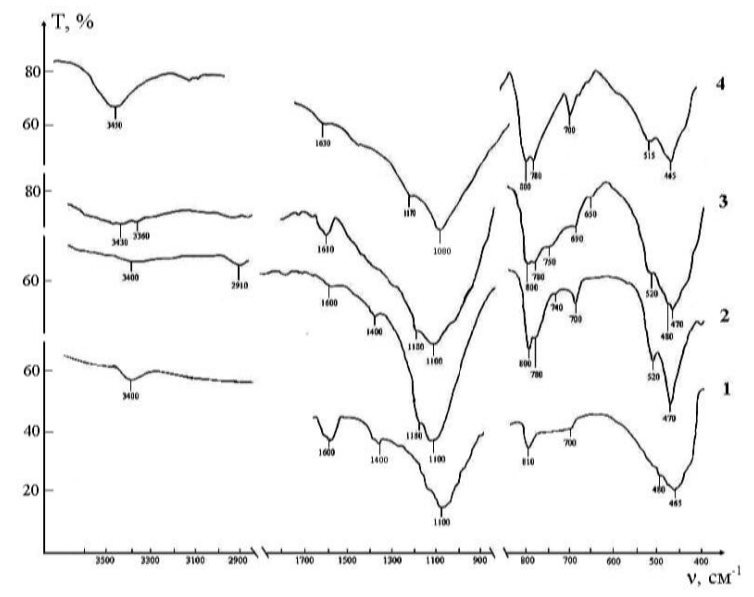

Fig. 6. IR absorption spectra of quartzite:

1 -initial quartzite; 2 - irradiation with $\gamma$-quanta up to a dose of $10^{6} \mathrm{~Gy} ; 3$-irradiation with $\gamma$-quanta up to a dose of $10^{7} \mathrm{~Gy} ; 4$-irradiation with $\gamma$-quanta up to a dose of $3.5 \cdot 10^{7} \mathrm{~Gy}$

After irradiation to a dose of $1 \cdot 10^{7}$ Gy the shape of the spectrum changes noticeably. The $\alpha$-quartz bands become less intense with diffused maxima; in addition, a number of small peaks typical for the hightemperature disordered modification of $\mathrm{SiO}_{2}-$ cristobalite - appear: 480,650 , and $750 \mathrm{~cm}^{-1}$. This is due to the intense crystallization of amorphous fringes around quartz grains with the formation of a cristobalite phase.

As a result of irradiation of quartzite to a maximum dose of $3.5 \cdot 10^{7} \mathrm{~Gy}$, all bands of the cristobalite phase disappear in the IR spectrum and the bands of lowtemperature $\alpha$-quartz with narrow clear maxima and characteristic doublets are clearly observed. Thus, the disordered high-temperature modification of silica transforms into an ordered modification. Considering the shape of the IR spectrum, irradiated quartzite no longer contains the amorphous phase that was present in the original sample. This is confirmed by the data of crystal optical analysis, which showed that after irradiation to a dose of $3.5 \cdot 10^{7} \mathrm{~Gy}$, the silica fringes around the quartz grains are completely composed of polycrystalline quartz (see Fig. 4).

As a result of irradiation changes in the IR spectrum are observed in the region of $\mathrm{OH}^{-}$hydroxyl groups stretching and bending vibrations (1600 and $\left.3400 \mathrm{~cm}^{-1}\right)$. After irradiation to a dose of $10^{6}$ Gy the intensity of the bands typical for $\mathrm{OH}^{-}$group's vibrations abruptly decreases (see Fig. 6, curve 2). This results in the loss of structural hydroxyl groups. After subsequent irradiation 
to a dose of $10^{7}$ Gy a doublet of weak intensity is formed in the region of 3360 and $3430 \mathrm{~cm}^{-1}$, corresponding to the stretching vibrations of $\mathrm{O}-\mathrm{H}$ in the structure of cristobalite and quartz, respectively (see Fig. 6, curve 3 ). Irradiation to a dose of $3.5 \cdot 10^{7}$ Gy leads to the formation of a band in the region of $3450 \mathrm{~cm}^{-1}$, which is common for vibrations of water molecules (see Fig. 6, curve 4). The reason for this may be the formation in quartz grains a large number of gas-liquid inclusions containing $\mathrm{H}_{2} \mathrm{O}$ as a result of radiationstimulated diffusion.

Table 2 data shows the gamma lines of quartzite samples. Lines of isotopes in quartzite after irradiation corresponded to following elements $\mathrm{Al}, \mathrm{Fe}, \mathrm{Mn}, \mathrm{Ca}, \mathrm{Ti}$, $\mathrm{Mg}$, $\mathrm{Na}$ from nuclear reactions ${ }^{27} \mathrm{Al}(\gamma, \alpha){ }^{23} \mathrm{Na}$, ${ }^{56} \mathrm{Fe}(\gamma, \mathrm{n}){ }^{55} \mathrm{Fe}, \quad{ }^{54} \mathrm{Mn}(\gamma, \mathrm{n}){ }^{53} \mathrm{Mn}, \quad{ }^{48} \mathrm{Ca}(\gamma, \mathrm{n}){ }^{47} \mathrm{Ca}$, ${ }^{54} \mathrm{Ti}(\gamma, \mathrm{n}){ }^{53} \mathrm{Ti},{ }^{24} \mathrm{Mg}(\gamma, \mathrm{n}){ }^{23} \mathrm{Mg},{ }^{23} \mathrm{Na}(\gamma, \mathrm{n}){ }^{22} \mathrm{Na} \rightarrow{ }^{22} \mathrm{Ne}$. The gamma spectrum also contains lines of the ${ }^{235,238} \mathrm{U}$ isotope.

Table 2

Lines of isotopes in quartzite after irradiation

\begin{tabular}{|c|c|c|c|c|}
\hline No. & $\begin{array}{c}\text { Energy, } \\
\mathrm{keV}\end{array}$ & $\begin{array}{c}\text { S, } \\
\text { counts }\end{array}$ & $\begin{array}{c}\text { Error, } \\
\%\end{array}$ & $\begin{array}{c}\text { Energy } \\
\text { resolution, keV }\end{array}$ \\
\hline 1 & 239 & 375 & 23 & 2.4 \\
\hline 2 & 322 & 254 & 25 & 2.2 \\
\hline 3 & 352 & 330 & 16 & 2.1 \\
\hline 4 & 375 & 106 & 47 & 1.8 \\
\hline 5 & 511 & 708 & 6.8 & 3.05 \\
\hline 6 & 546 & 102 & 38 & 1.5 \\
\hline 7 & 609 & 375 & 11 & 2.9 \\
\hline 8 & 727 & 64 & 50 & 1.5 \\
\hline 9 & 794 & 78 & 36 & 1.8 \\
\hline 10 & 912 & 138 & 22 & 2.05 \\
\hline 11 & 1461 & 170 & 5 & 3.3 \\
\hline
\end{tabular}

The elements that make up quartzite are oxides in terms of their chemical composition. It is well known that gamma radiation can cause point defects in oxides. Under the influence of $\gamma$-irradiation the radiochemical decomposition of substances, oxidation processes occur intensively. Radiolysis under the action of $\gamma$-quanta and recoil atoms of natural radioisotopes occurs throughout the entire volume of the samples. In the zones of possible micro-damage to the lattice, these processes are, as a rule, extreme. In any oxidative processes, the main role is played by radicals $\left(\mathrm{H}^{*}, \mathrm{OH}^{*}, \mathrm{H}_{2} \mathrm{O}_{2}\right)$ formed during radiolysis of water, as well as surface radiation defects. It can be expected that various radiation defects (vacancies, cations, anions, etc.) caused by $\gamma$-irradiation and Auger electrons emitted by radionuclides will lead to an increase in the concentration of active centers on the oxide surface and, as a consequence, to the more ordered crystal structure of quartzite.

\section{CONCLUSIONS}

It was established that there is an intensive formation of opaque point inclusions in quartz grains, forming clusters and oriented chains as a result of irradiation of natural quartzites with $\gamma$-quanta in the dose range of $1 \cdot 10^{6} \ldots 3.5 \cdot 10^{7} \mathrm{~Gy}$. At the same time the crystal structure of the initial $\alpha$-quartz in quartzite is preserved, and, taking into account the data of IR spectroscopy and XRD analysis, there are signs of its improve- ment, which happens because of radiation-stimulated diffusion of impurities and radiation annealing of the structural defects in the initial quartz. The sequence of transformations of semi-amorphous silica cement around quartz grains has been determined. With an increase of the radiation dose, its crystallization is observed along with the formation of cristobalite at the initial stage and its transition at the maximum radiation dose $\left(3.5 \cdot 10^{7} \mathrm{~Gy}\right)$ into polycrystalline quartz. But these processes do not lead to cracking of quartzite rock.

Optimal conditions for gamma activation by bremsstrahlung of natural quartzite were worked out to determine the content of impurities in them. A wide range of isotopic elemental composition is shown. This is important for determining the properties of the studied structures and for predicting their further usage.

The obtained data indicate the high radiation resistance of the quartz deposit and confirm the prospects of using this geological form as a natural barrier for the construction of a radioactive waste storage facility.

\section{REFERENCES}

1. V. Shestopalov, Y. Shibetsky, L. Kuzov. Petrophysical criteria for assessing the suitability of crystalline rocks for geological disposal of radwaste. Kyiv: "Proceedings of the Institute of Environmental Geochemistry", 2010, p. 118-128.

2. V.V. Skvortsov, N.V. Aleksandrova. Investigation of the structure of the Kiev tier in the exclusion zone with the purpose of finding the Precambrian foundation site for radioactive waste disposal: Collection of scientific works. Kiev: "Institute of Environmental Geochemistry", 2010, p. 129-139.

3. V.M. Shestopalova. Isolation of radioactive waste in the bowels of Ukraine (problems and possible solutions). Kiev: NAS of Ukraine, SIC RPI, 2006, 398 p.

4. E.P. Shevyakova, B.V. Borts, E.P. Bereznyak, L.A. Sayenko. The effect of electron irradiation on the structure and properties of natural quartzites of Ukraine // Problems of Atomic Science and Technology. Series "Physics of Radiation Damage and Radiation Materials Science". 2010, N 1, p. 36-41.

5. E.P. Bereznyak, I.V. Kolodiy, Yu.S. Khodyreva. The effect of the external medium on the structural phase transformation of quartzite upon high-energy electron irradiation // Problems of atomic science and technology. Series "Physics of Radiation Damage and Radiation Materials Science”. 2019, N5(123), p. 30-34.

6. I.L. Komov. Radiation mineralogy and geochemistry. Kiev: "Naukova dumka", 2006, 439 p.

7. S.Yu. Saenko, I.M. Neklyudov, G.A. Kholomeev, B.A. Shilyaev, R.V. Tarasov. Mathematical modeling of heat and mass transfer in a geological protective barrier after the disposal of spent nuclear fuel // Nuclear and radiation safety. 2001, N 4, p. 66-72.

8. N.P. Dikiy, A.N. Dovbnya, V.L. Uvarov. Development of new trends in applied physics with the use of high-energy braking radiation // Problems of Atomic Science and Technology. Series "Nuclear Physics Investigations". 1999, N 3, p. 91-92.

9. I.M. Simanovich. Quartz sand rocks. M.: "Nauka", 1978, 156 p. 


\title{
АНАЛИЗ СТРУКТУРНЫХ ПРЕОБРАЗОВАНИЙ В ПРИРОДНЫХ КВАРЦИТАХ ПОД ВЛИЯНИЕМ ОБЛУЧЕНИЯ $\gamma$-КВАНТАМИ
}

\author{
Е.П. Березняк, Н.П. Дикий, И.В. Колодий, Е.П. Медведева, Ю.С. Ходырева
}

С помощью методов ИК-спектроскопии, кристаллооптического и рентгеноструктурного анализов изучена эволюция структуры природных кварцитов Овручского месторождения под влиянием облучения $\gamma$-квантами в интервале поглощенных доз $\mathrm{D}_{\text {погл }}=10^{6} \ldots 3,5 \cdot 10^{7}$ Гр. Определен элементный состав природных кварцитов методом гамма-активации на линейном ускорителе электронов. Установлено, что в результате облучения кристаллическая структура кварца, составляющего основу кварцита, совершенствуется вследствие радиационного отжига дефектов исходной структуры. Одновременно происходит кристаллизация аморфного кремнезема, окаймляющего крупные зерна кварца, с превращением его в мелкокристаллический кварц. Эти процессы не приводят к трещинообразованию в кварцитовой породе. Полученные данные свидетельствуют о высокой радиационной стойкости кварцитов Овручского месторождения и подтверждают перспективность использования данной геологической формации в качестве природного барьера для сооружения долговременного хранилища радиоактивных отходов.

\section{АНАЛІЗ СТРУКТУРНИХ ПЕРЕТВОРЕНЬ У ПРИРОДНИХ КВАРЦИТАХ ПІД ВПЛИВОМ ОПРОМІНЕННЯ $\gamma$-КВАНТАМИ}

\section{О.П. Березняк, М.П. Дикий, І.В. Колодий, О.П. Медведєва, Ю.С. Ходирєва}

За допомогою методів ІЧ-спектроскопії, кристалооптичного та рентгеноструктурного аналізів вивчена еволюція структури природних кварцитів Овруцького родовища під впливом $\gamma$-опромінення в інтервалі поглинених доз $\mathrm{D}_{\text {погл }}=10^{6} \ldots 3,5 \cdot 10^{7}$ Гр. Визначений елементний склад природних кварцитів методом гаммаактивації на лінійному прискорювачі електронів. Встановлено, що в результаті опромінення кристалічна структура кварцу, що становить основу кварциту, вдосконалюється внаслідок радіаційного відпалу дефектів вихідної структури. Одночасно відбувається кристалізація аморфного кремнезему, що окаймляє великі зерна кварцу, з перетворенням його в дрібнокристалічний кварц. Ці процеси не призводять до утворення тріщин у кварцитовій породі. Отримані дані свідчать про високу радіаційну стійкість кварцитів Овруцького родовища і підтверджують перспективність використання даної геологічної формації як природного бар'єру для спорудження довготривалого сховища радіоактивних відходів. 